\title{
Effect of ZnO nanoparticles on methicillin, vancomycin, linezolid resistance and biofilm formation in Staphylococcus aureus isolates
}

\author{
Wedad M. Abdelraheem, Rasha M. M. Khairy", Alaa I. Zaki and Shaimaa H. Zaki
}

\begin{abstract}
Background: Multidrug resistant (MDR) and biofilm producing Staphylococcus aureus strains are usually associated with serious infections. This study aimed to evaluate the antibacterial and antibiofilm-formation effects of zinc oxide nanoparticles (ZnO-NPs) against staphylococcus aureus (S. aureus) isolates.

Methods: A total of 116 S. aureus isolates were recovered from 250 burn wound samples. The antimicrobial/antibiofilm effects of ZnO-NPs against methicillin, vancomycin and linezolid resistant S. aureus (MRSA, VRSA and LRSA) isolates were examined using phenotypic and genotypic methods. The minimum inhibitory concentration (MIC) of ZnO-NPs was determined by microdilution method. The effects of sub-MIC concentrations of ZnO-NPs on biofilm formation and drug resistance in $\mathrm{S}$. aureus were determined by the microtiter plate method. The change in the expression levels of the biofilm encoding genes and resistance genes in S. aureus isolates after treatment with ZnO-NPs was assessed by real time reverse transcriptase PCR (rt-PCR).
\end{abstract}

Results: MICs of ZnO-NPs in S. aureus isolates were (128-2048 $\mu \mathrm{g} / \mathrm{ml})$. The sub-MIC of ZnO-NPs significantly reduced biofilm formation rate (the highest inhibition rate was $76.47 \%$ at $1024 \mu \mathrm{g} / \mathrm{ml}$ ) and the expression levels of biofilm genes (ica A, ica D and fnb A) with $\mathrm{P}<0.001$. Moreover, Sub-MIC of ZnO-NPs significantly reduced the rates of MRSA from 81.9 (95 isolates) to $13.30 \%$ (15 isolates), VRSA from 33.60 (39 isolates) to 0\% and LARSA from 29.30 (34) to 0\% as well as the expression levels of resistance genes ( $m e c A$, van $A$ and $c f r$ ) with $P$ value $<0.001$.

Conclusion: ZnO-NPs can be used as antibiofilm and potent antimicrobial against MRSA, VRSA and LRSA isolates.

Keywords: MRSA, VRSA, LRSA, Biofilm, ZnO-NPs

\section{Background}

Staphylococcus aureus (S. aureus) is an important human pathogen which cause a variety of clinical infections [1]. In the past few decades, the treatment of infections caused by $S$. aureus had become a big challenge due to emergence of multi-drug resistant strains such as Methicillin-Resistant Staphylococcus aureus (MRSA) in community and hospital settings [2]. Methicillin resistance is

*Correspondence: rashakhiry1@gmail.com; rashakhiry@mu.edu.eg Department of Microbiology and Immunology, Faculty of Medicine, Minia University, Minia 61511, Egypt caused by mecA or mecC gene, encoding penicillin-binding protein (PBP2a) or (PBP2ALGA) with low affinity for $\beta$-lactams [3]. For treatment of MRSA, vancomycin was used as the drug of choice for decades [4]. However, vancomycin resistant $S$. aureus (VRSA) isolates and vancomycin intermediate resistant $S$. aureus (VISA) have emerged [5]. Vancomycin resistant S. aureus (VRSA) is mediated by vanA gene cluster, which is transmitted by vancomycin resistant enterococci $[4,6]$. Linezolid is an oxazolidinone which has become a good alternative to vancomycin in the treatment of infections caused by gram-positive organisms, including VRSA or VISA isolates [7]. Unfortunately, Linezolid resistance among $S$. original author(s) and the source, provide a link to the Creative Commons licence, and indicate if changes were made. The images or other third party material in this article are included in the article's Creative Commons licence, unless indicated otherwise in a credit line to the material. If material is not included in the article's Creative Commons licence and your intended use is not permitted by statutory regulation or exceeds the permitted use, you will need to obtain permission directly from the copyright holder. To view a copy of this licence, visit http://creativecommons.org/licenses/by/4.0/. The Creative Commons Public Domain Dedication waiver (http://creativeco mmons.org/publicdomain/zero/1.0/) applies to the data made available in this article, unless otherwise stated in a credit line to the data. 
aureus isolates (LRSA) was reported in USA shortly after its use [8]. Development of Linezolid resistance in these early studies was due to mutation in the 23S rRNA gene, but it seemed to be an uncommon finding $[9,10]$. However, a different mechanism of Linezolid resistance has reported: the acquisition of plasmid-mediated ribosomal methyltransferase $c f r$ gene, which also mediates chloramphenicol resistance $[11,12]$. In addition to development of multi-drug resistance among $S$. aureus strains, biofilm formation is reported as an important cause of treatment failure and recurrent infections [13]. Biofilm formation by $S$. aureus is encoded by (ica) ADBC genes which mediate synthesis of polysaccharide intracellular adhesin (PIA) [14]. Therefore, detection of one or more of these genes can determine the ability of $S$. aureus strains to produce biofilm [15]. Biofilm protects the organism from antimicrobials and also from killing by the host immune system [13]. With the emergence, spread, and persistence of resistance to different antimicrobials, the development of novel and effective alternatives to the traditional antibiotics has become an urgent need. The progressions in nanotechnology hold a promising future of nanomaterials as antimicrobial agents. Nanomaterials have a broader microbicidal spectrum than traditional antibiotics [16]. $\mathrm{ZnO}$ nanoparticles ( $\mathrm{ZnO}-\mathrm{NPs}$ ) have been identified as one of the most promising metallic nanomaterials. In recent years, there is an increasing interest in $\mathrm{ZnO}$-NPs as effective antibacterial agents due to their safety and stability for human cells $[17,18]$. The current study aimed to use phenotypic and molecular methods to assess the efficacy of ZnO-NPs against MRSA, VRSA, LRSA and biofilm formation among $S$. aureus isolated from burn wounds.

\section{Materials and methods}

In this cross sectional study, a total of 250 burn wound samples of 250 burn patients who attending outpatient's clinics of the plastic surgery department, Minia university hospital were collected from April 2019 to December 2019. Patients with clinical findings of burn wound infection, such as erythema, swelling and sepsis were included. This study was carried following the guidelines of the declaration of Helsinki and approved by the Medical Ethics Committee of Faculty of medicine, Minia University, Egypt. Informed consent was obtained from each participant.

\section{Bacterial isolation}

Out of 250 samples, 116 S. aureus isolates were identified according to the standard methods using Gram staining, catalase test, tube coagulase test, DNase agar and cultivation on mannitol salt agar. Staphylococcus aureus isolates were confirmed by identification of $16 s R N A$ gene expression among all 116 S. aureus isolates. Confirmed $S$. aureus isolates were kept in trypticase soy broth with sterilized $15 \%$ glycerol at $-20{ }^{\circ} \mathrm{C}$.

\section{Antibacterial activity of ZnO-NPs}

$\mathrm{ZnO}-\mathrm{NPs}$ with an average particle size of $30 \mathrm{~nm}$ and purity of above $99 \%$ was used in the study (Sigma Aldrich, St. Louis, MO, USA). Stock solution of ZnO-NPs was prepared by dissolving $\mathrm{ZnO}-\mathrm{NPs}$ in propylene glycol in the highest concentration $(1000 \mu \mathrm{g} / \mathrm{ml})$. MIC values of $\mathrm{ZnO}-\mathrm{NPs}$ for all $S$. aureus isolates were determined by broth micro-dilution method using sterile 96-well microplates. Gradient concentrations of ZnO-NPs (0.50$4096 \mu \mathrm{g} / \mathrm{ml}$ ) were inoculated with $100 \mu \mathrm{l}$ of bacterial suspension of each isolate with turbidity equivalent to 0.5 Mc-Farland in the tubes. Tubes with culture media and microbial suspension without nanoparticles were used as positive control and tubes with sterile broth were used as negative control. The plates were incubated overnight at $37{ }^{\circ} \mathrm{C}$. MIC is the lowest concentration of the $\mathrm{ZnO}-\mathrm{NPs}$ that inhibit visible bacterial growth [19]. After identification of MIC value for each isolate, sub-inhibitory concentrations $(1 / 2 \mathrm{MIC})$ were calculated. All experiments were carried out three times.

\section{Phenotypic identification of MRSA, VRSA and LRSA using micro-dilution method}

MICs of oxacillin, vancomycin and linezolid in S. aureus isolates were determined by micro-dilution method using sterile 96-well microplates. Commercial oxacillin, vancomycin hydrochloride (MYLAN S.A.S Company, France) and linezolid infusion (Averroes pharma company, Egypt) were prepared in the highest concentration to be used. The MICs of each antimicrobial agent were determined and interpreted according to CLSI 2019 guidelines [20].

\section{Molecular identification of MRSA, VRSA and LRSA}

Bacterial RNA was extracted by Easy-spin ${ }^{\mathrm{TM}}$ Total RNA Extraction Kit (iNtRON biotechnology, South Korea) and lysozyme $10 \mathrm{mg} / \mathrm{ml}$ from $S$. aureus isolates according to the manufacturer's instructions. Gene expression of antimicrobial resistance genes (mec $A$ for methicillin, van $A$ for vancomycin and $c f r$ for Linezolid) were tested using quantitative real-time reverse transcriptase-polymerase chain reaction (rt-PCR). $16 \mathrm{~s}$ $R N A$ gene was used as a reference gene. One step Sybr green kits (SensiFAST SYBR Lo-ROX Kit, Meridian Life science, UK) were used according to manufacturer's instructions. Primers used in the study were listed in Table 1. Each rt-PCR reaction was prepared with a final volume of $20 \mu \mathrm{g}$ (master mix: $10 \mu \mathrm{g}$, Forward primer: $0.8 \mu \mathrm{g}$, Reverse primer: $0.8 \mu \mathrm{g}$, Reverse transcriptase: $0.2 \mu \mathrm{g}$, RNase inhibitor, $0.4 \mu \mathrm{g}$, Water up to $16 \mu \mathrm{g}$ and 
Table 1 The Primers sequence of the tested genes

\begin{tabular}{|c|c|c|}
\hline Gene & Sequence & References \\
\hline \multirow[t]{2}{*}{$i c a A$} & F:5'-ACACTTGCTGGCGCAGTCAA-3' & {$[21]$} \\
\hline & R:5'-TCTGGAACCAACATCCAACA-3' & \\
\hline \multirow[t]{2}{*}{$i c a B$} & F:5'-AGAATCGTGAAGTATAGAAAATT-3' & {$[22]$} \\
\hline & R:5'-TCTAATCTTTTTCATGGAATCCGT-3' & \\
\hline \multirow[t]{2}{*}{$i c a D$} & F:5'-ATGGTCAAGCCCAGACAGAG-3' & {$[23]$} \\
\hline & R:5'- AGTATTTTCAATGTTTAAAGCAA-3' & \\
\hline \multirow[t]{2}{*}{$f \cap b A$} & F:5'-CATAAATTGGGAGCAGCATCA-3' & [24] \\
\hline & R:5'-ATCAGCAGCTGAATTCCCATT-3' & \\
\hline \multirow[t]{2}{*}{ mecA } & F:5'-GTAGAAATGACTGAACGTCCGATAA-3' & {$[25]$} \\
\hline & R:5'-CCAATTCCACATTGTTTCGGTCTAA-3' & \\
\hline \multirow[t]{2}{*}{ vanA } & F:5'-CATGAATAGAATAAAAGTTGCAATA-3' & {$[26]$} \\
\hline & R:5'-CCCCTTTAACGCTAATACGACGATCAA-3' & \\
\hline \multirow[t]{2}{*}{$c f r$} & F:5-TGAAGTATAAAGCAGGTTGGGAGTCA3' & {$[26]$} \\
\hline & R: 5'-ACCATATAATTGACCACAAGCAGC-3' & \\
\hline \multirow[t]{2}{*}{ 16SrRNA } & F:5'-GTA GGT GGC AAG CGT TAT CC-3' & {$[27]$} \\
\hline & R:5'-CGCACATCAGCGTCAG-3' & \\
\hline
\end{tabular}

template: $4 \mu \mathrm{g}$ ). Negative control samples contain deionized water instead of template were used with each run. The conditions of the different reactions were adjusted according to kits protocol as follows: reverse transcription for $10 \mathrm{~min}$ at $45^{\circ} \mathrm{C}$, Polymerase activation for $2 \mathrm{~min}$ at $95{ }^{\circ} \mathrm{C}$, then 40 cycles of denaturation for $5 \mathrm{~s}$ at $95{ }^{\circ} \mathrm{C}$ and annealing/extension for $20 \mathrm{~s}$ at $60^{\circ} \mathrm{C}$. PCR products were analyzed by gel electrophoresis, to exclude any unspecific products.

\section{Biofilm formation testing among S. aureus isolates}

The isolated organisms were tested for their ability to form biofilm as previously described [28]. Each isolate was inoculated into trypticase-soy broth and incubated overnight. After adjusting the turbidity of bacterial suspensions to the turbidity of 0.5 McFarland, $100 \mu \mathrm{l}$ of each isolate was inoculated into sterile 96 well microtiter plate except last column that used as negative control. The inoculated plate was incubated for $24 \mathrm{~h}$. The contents of wells were gently decanted and washed by saline. The wells were stained by $150 \mu \mathrm{l}$ of crystal violet (0.2\%) for $15 \mathrm{~min}$ at room temperature. The stain was gently discarded and wells were washed by water. The plate was dried at room temperature and the crystal violet in stained cells was solubilized with $95 \%$ ethanol. The optical density (OD) of each well was measured at $620 \mathrm{~nm}$ by ELISA reader. The average OD values were calculated for all tested isolates and negative controls. The isolates were divided into four categories non biofilm, weak, moderate and strong biofilm producer as previously described [28].
Molecular identification of biofilm formation among $S$. aureus isolates

Gene expression of biofilm encoding genes (ica A, ica $B$, ica $D$ and $f n b A$ ) were tested using quantitative realtime reverse transcriptase-polymerase chain reaction (rt-PCR). $16 s$ RNA gene was used as a reference gene. One step Sybr green kits (SensiFAST SYBR Lo-ROX Kit, Meridian Life science, UK) were used according to manufacturer's instructions. Primers used were listed in Table 1

\section{Phenotypic identification of MRSA, VRSA and LRSA after application of ZnO-NPs}

Sub-inhibitory concentration of ZnO-NPs (1/2 MIC) of each sample was measured and added to wells that inoculated by bacterial broth adjusted to the turbidity of 0.5 McFarland standard then, the plates were incubated at $37{ }^{\circ} \mathrm{C}$ for $24 \mathrm{~h}$. Micro-dilution tests for oxacillin, vancomycin and linezolid were repeated with the same previous steps to all $\mathrm{ZnO}$-NPs treated isolates and MICs were determined according to CLSI 2019 guidelines [20].

\section{Biofilm formation testing among S. aureus isolates after ZnO-NPs application}

Biofilm-forming isolates were inoculated in trypticasesoy broth and incubated $24 \mathrm{~h}$ at $37^{\circ} \mathrm{C}$. About $100 \mu \mathrm{l}$ of each isolate' suspension was inoculated into sterile 96 well microtiter plate and mixed with $100 \mu \mathrm{l}$ of $1 / 2 \mathrm{MIC}$ of $\mathrm{ZnO}$-NPs. The microplate was incubated at $37^{\circ} \mathrm{C}$ until the biofilm formation. The results were interpreted by ELISA plate reader at $620 \mathrm{~nm}$ using the same steps that used before.

\section{Effect of ZnO-NPs on genes expression}

Gene expression of biofilm encoding genes (ica $A$, ica $B$, ica $D$ and $f n b A$ ) and antimicrobial resistance genes (mec $A$ for methicillin, van $A$ for vancomycin and $c f r$ for Linezolid) were tested using quantitative real-time reverse transcriptase-polymerase chain reaction (rt-PCR) after treating of $S$. aureus isolates with sub-inhibitory concentration of $\mathrm{ZnO}-\mathrm{NPs}$ (1/2 MIC) of each sample and incubating the plates at $37^{\circ} \mathrm{C}$ for $24 \mathrm{~h}$, bacterial RNA was extracted again using the same method that used before. Gene expression of biofilm encoding genes and antimicrobial resistance genes were tested again using the same method that used before. PCR products were analyzed by gel electrophoresis, to exclude any unspecific products. The relative expression of target genes was calculated using the equation; $R Q=2^{-\Delta \Delta C t}$ as described previously [29]. 


\section{Statistical analysis}

All data collected in this study were stored in a computer database. Statistical analysis was done on SPSS package version 23.0 (SPSS Inc., Chicago, IL, USA). Chi-squared tests were performed for categorical data, while Mann Whitney $U$ test and $Z$ test were performed for comparison of continuous data. Roc curve analysis was used to detect specificity and sensitivity of the used methods.

\section{Results}

\section{Isolation of S. aureus}

Out of 250 wound samples, 116 (46.40\%) isolates were identified as S. aureus.

\section{Antibacterial activity of ZnO-NPs}

MICs of $\mathrm{ZnO}-\mathrm{NPs}$ among $S$. aureus isolates were (128$2048 \mu \mathrm{g} / \mathrm{ml}$ ) as presented in Fig. 1.

\section{Effect of ZnO-NPs on biofilm formation}

All isolates of $S$. aureus (116) were tested for their ability to form biofilm using microtiter plate; $31 / 116$ (26.70\%) were non-biofilm producers and 85 (73.30\%) were biofilm producers (weak: 44/116 (38\%); moderate 32/116 (28\%); and strong: 9/116 (8\%). The frequencies MRSA, VRSA and LRSA among biofilm and non-biofilm producers were presented in Table 2. All biofilm producers (85) were tested for their ability to form biofilm after treating with 1/2 MIC of ZnO-NPs of each isolate. ZnO-NPs at a concentration of $1024 \mathrm{ug} / \mathrm{ml}$ could inhibit biofilm formation in $76.47 \%(65 / 85)$ of biofilm producing isolates. There was a positive correlation between concentrations of $\mathrm{ZnO}-\mathrm{NPs}$ and the rates of biofilm formation inhibition (Fig. 2).

\section{Effect of ZnO-NPs on MRSA, VRSA and LRSA among $S$. aureus isolates}

Micro-dilution method was used to identify MRSA, VRSA and LRSA. The prevalence of MRSA (isolates with MIC of $\geq 4 \mu \mathrm{g} / \mathrm{mL}$ for oxacillin) was $95 / 116(82 \%)$. The prevalence of VRSA (isolates with MIC $\geq 16 \mu \mathrm{g} / \mathrm{mL}$ to vancomycin) was 39/116 (34\%) and VISA (isolates with MIC $4-8 \mathrm{ug} / \mathrm{mL}$ to vancomycin) was $6 / 116(5.17 \%)$. The prevalence of LARSA (isolates with $\mathrm{M} \mathrm{IC} \geq 8 \mu \mathrm{g} / \mathrm{mL}$ to linezolid) was 34/116 (29.3\%).

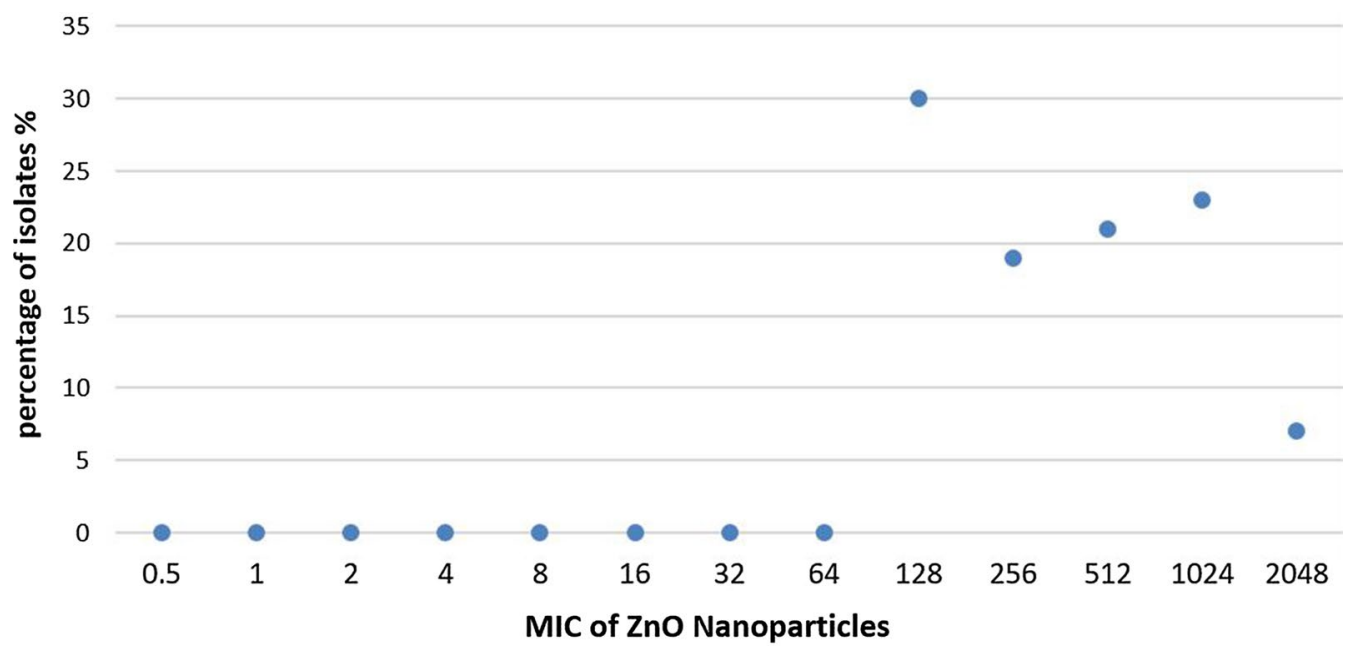

Fig.1 MICs of ZnO-NPs in all S. aureus isolates

Table 2 The frequencies MRSA, VRSA and LRSA among biofilm and non-biofilm producers

\begin{tabular}{|c|c|c|c|c|c|c|}
\hline \multirow[t]{3}{*}{ Antibiotic resistance } & \multicolumn{4}{|l|}{ Biofilm production } & \multicolumn{2}{|c|}{ Chi-squared } \\
\hline & \multicolumn{2}{|c|}{ Non-biofilm producer $\mathrm{N}=30$} & \multicolumn{2}{|c|}{ Biofilm producer $\mathrm{N}=86$} & \multirow[t]{2}{*}{$\mathrm{x}^{2}$} & \multirow[t]{2}{*}{ p-value } \\
\hline & Resistance freq. (\%) & Sensitivity freq. (\%) & Resistance freq. (\%) & Sensitivity freq. (\%) & & \\
\hline Oxacillin & $23(76.6 \%)$ & $7(23.4 \%)$ & $72(83.72 \%)$ & $14(16.28 \%)$ & 0.747 & 0.388 \\
\hline Vancomycin & $17(56.6 \%)$ & $13(43.4 \%)$ & $22(25.58 \%)$ & $64(74.42 \%)$ & 10.549 & 0.005 \\
\hline Linezolid & $14(46.66 \%)$ & $16(53.34 \%)$ & $20(23.25 \%)$ & $66(76.75 \%)$ & 5.883 & 0.015 \\
\hline
\end{tabular}

P-value $\leq 0.05$ is significant 


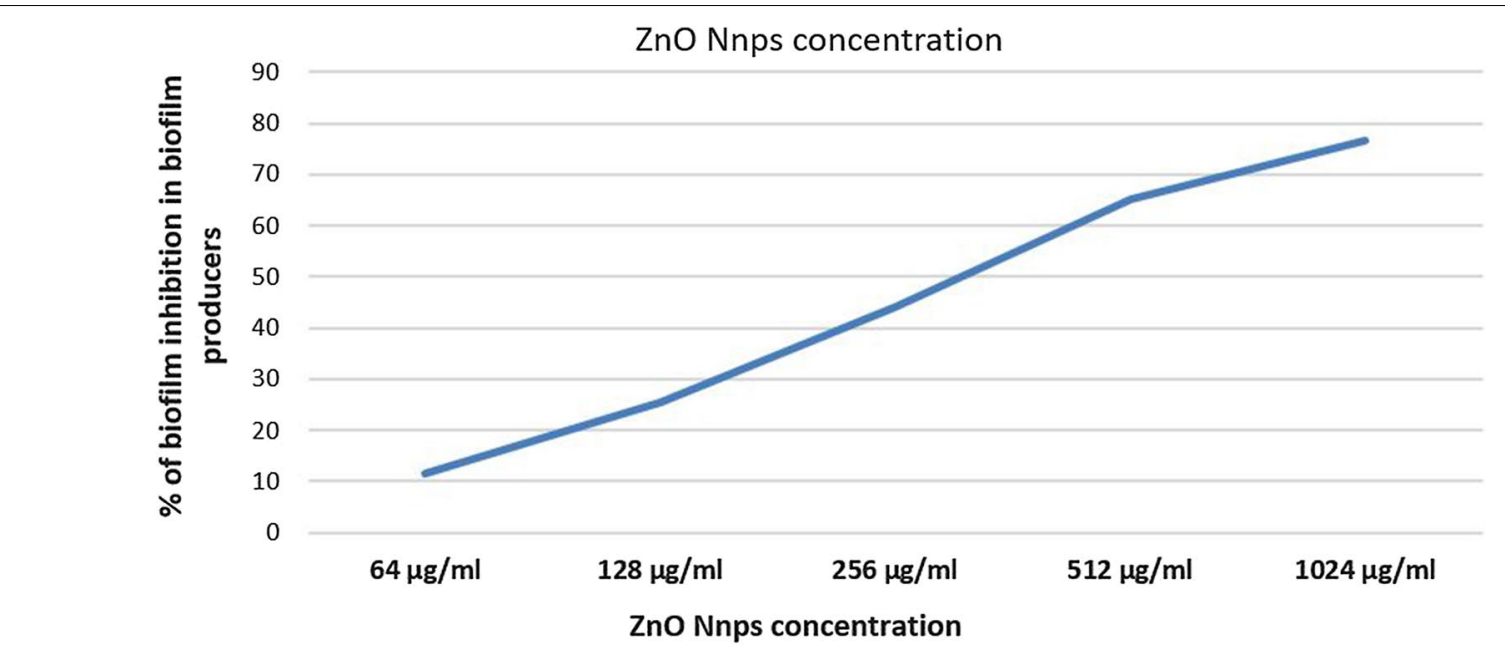

Fig. 2 Correlation between biofilm inhibition and $\mathrm{ZnO}-\mathrm{NPs}$ concentrations

MICs identification was repeated after treatment of all isolates with 1/2 MIC of ZnO-NPs. MRSA decreased from 81.9 (95 isolates) to $13.3 \%$ (15 isolates), VRSA decreased from 33.60 (39 isolates) to 0\% and LARSA decreased from 29.30 (34) to 0\% (Fig. 3). This decrease was statistically significant as p values were $\leq 0.005$.

\section{Effect of ZnO-NPs on genes expression}

Using real time RT-PCR; ica $A$ gene and fnb $A$ gene expressed in 116 isolates (100\%) of $S$. aureus isolates and ica D expressed in 96 isolates (82.7\%). However ica
$B$ gene was not detected in the study isolates. Regarding antimicrobial resistance genes, the rate of mec $A$ expression among $S$. aureus isolates was (94 isolates; $81 \%$ ), van $A$ was (22 isolates; $18.96 \%$ ) and $c f r$ gene was (29 isolates; 25\%). Antimicrobial resistance genes were not detected in sensitive or intermediate resistant isolates. Analyzing expression levels of biofilm encoding genes (ica $A$, ica $B$, ica $D$ and fnb $A$ ) among $S$. aureus isolates compared to their expression levels after treating of the isolates with $\mathrm{ZnO}-\mathrm{NPs}$ using Mann-Whitney $U$-test revealed that; there was statistically significant

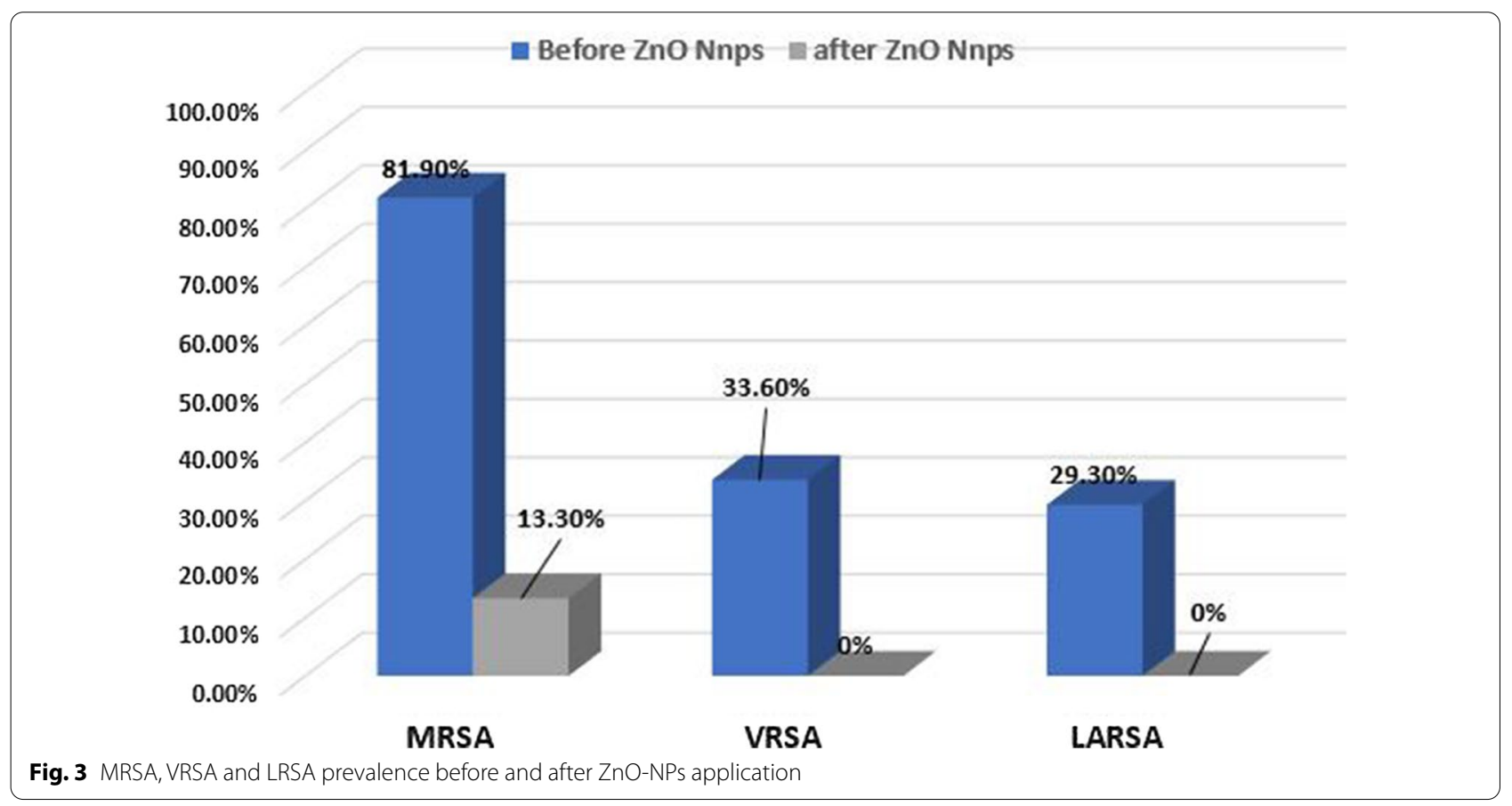




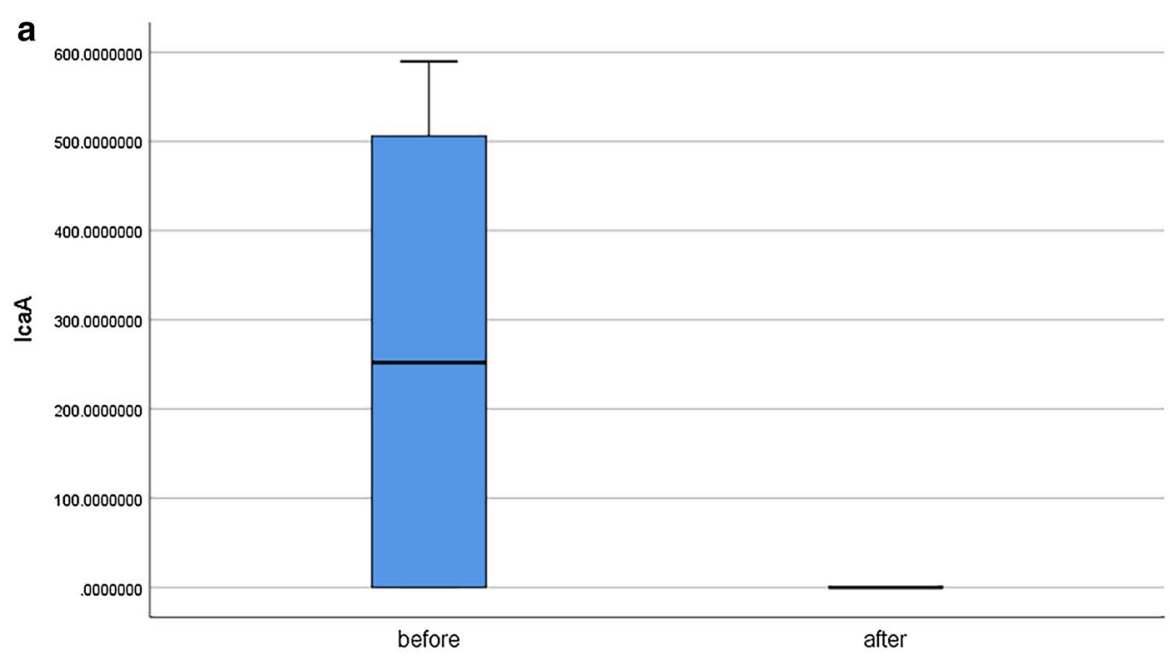

b

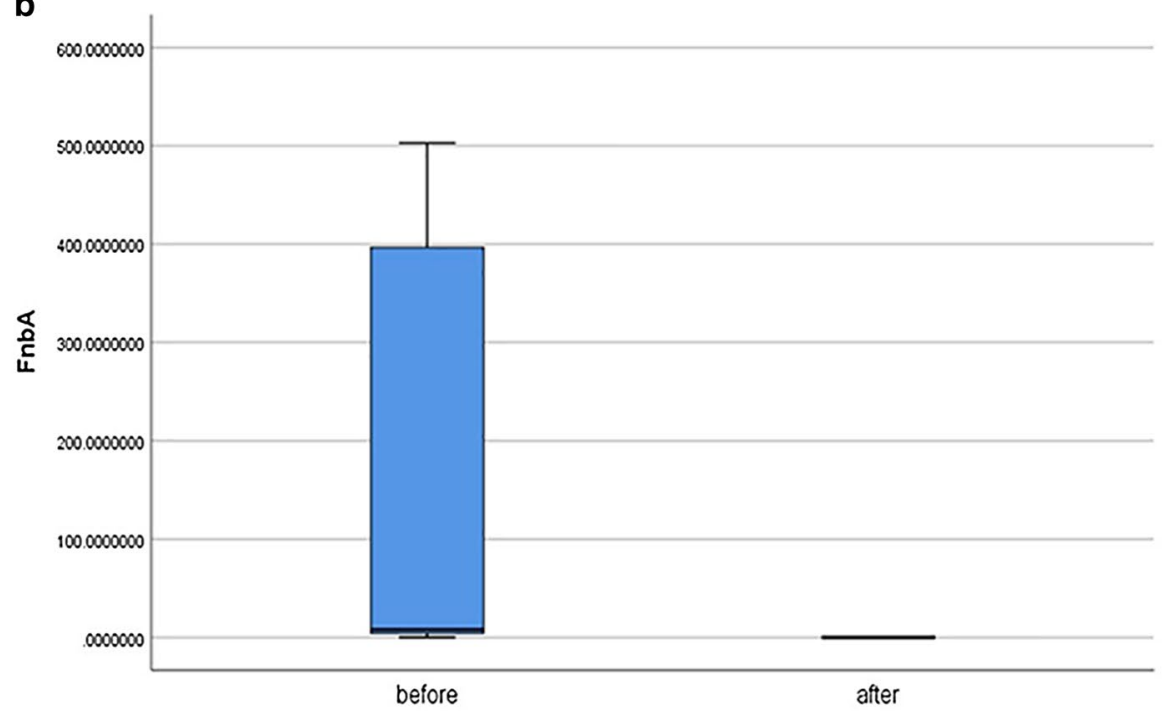

C

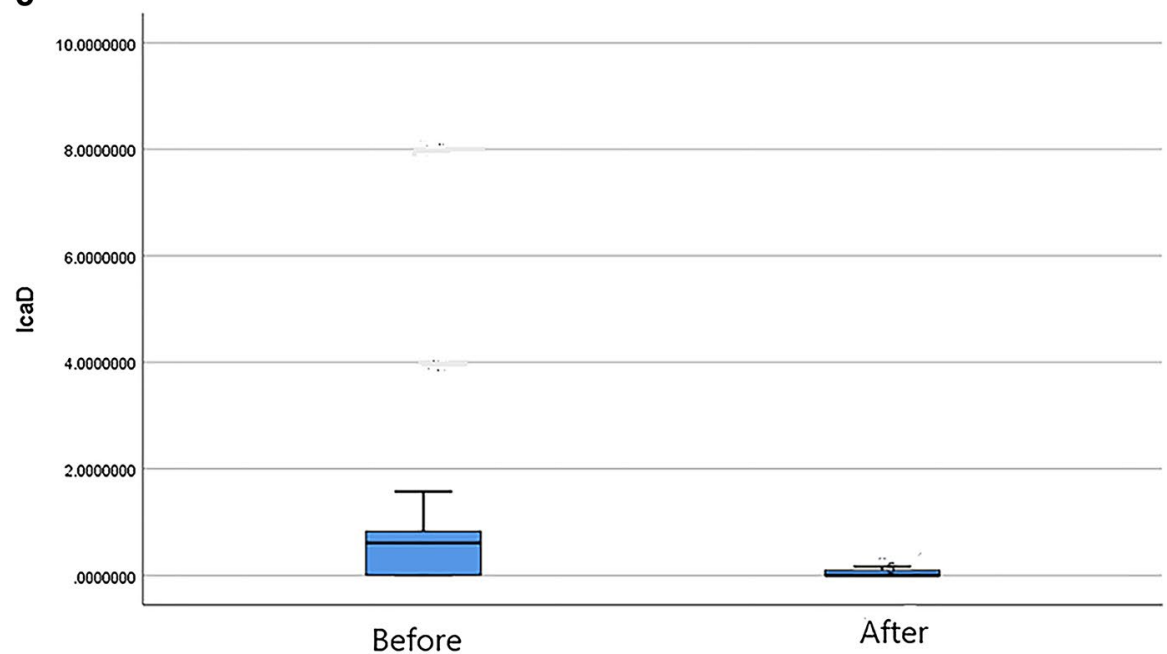

Fig. 4 a Expression of icaA gene before and after ZnO-NPs application, P-value $=0.005$. b Expression of icaD gene before and after ZnO-NPs application, P-value $=0.005$. $\mathbf{c}$ Expression of fnb A gene before and after ZnO-NPs application, P-value $=0.008$ 
decrease of the expression levels of ica $A$, ica $D$ and $f n b$ $A$ genes after treating of the $S$. aureus isolates with $\mathrm{ZnO}$ NPs $(\mathrm{P}<0.001$, for each) (Fig. 4a-c; Additional file 1 : Table S1). As regards to antimicrobial resistance genes (mec $A$, van $A$ and $c f r$ ); the expression levels of the three genes significantly decreased after treating of $S$. aureus isolates with $\mathrm{ZnO}-\mathrm{NPs}(\mathrm{P}<0.001$, for each) as shown in (Fig. $5 \mathrm{a}-\mathrm{c}$ ). The receiver operating characteristic curve (ROC) analysis using the expression levels of the studied genes was used to assess the accuracy of these results and revealed that; there were highly significant decreases in the expression levels of the studied genes after treating isolates with sub-MICs of ZnO-NPs with high sensitivity and specificity as shown in (Table 3 ).।

\section{Discussion}

The multidrug resistant strains of $S$. aureus are increasing, making the treatment more difficult. The prevalence of MRSA among S. aureus isolates is the highest in Egypt compared to other African countries [30]. The prevalence of MRSA in Egypt is ranging from 24 to 82\% [31], which is comparable with the prevalence reported in the current study $(95 / 116,81.90 \%)$. Our prevalence is comparable also with other reports from developing countries; (80\%) [32], 75\% [33] and 76\% [34]. The most effective drugs against MRSA are vancomycin and linezolid [35], however, isolates with reduced susceptibility to vancomycin are increasing [36]. The global prevalence of VRSA and VISA before 2010 was $1.2 \%$ and after 2010 were $2.40 \%$ and $4.3 \%$ respectively and the prevalence of VRSA in Egypt was 5.50\% [37]. However, the current study has reported a high prevalence of VRSA and VISA; 33.62\% $(39 / 116)$ and $5 \%(6 / 116)$ respectively, that agrees with a similar report from Egypt [33] where the author reported that $20.68 \%$ of the isolates were VISA, and $20.68 \%$ were VRSA. In Egypt, yet a few researches studied the resistance against linezolid among staphylococcal isolates using phenotypic methods only, where the prevalence of LRSA ranged from 5 to $15.4 \%$ [38, 39]. The prevalence of LRSA in the current study was (34/116, 29.31\%), that is higher than the previous Egyptian reports. Harcharan singh et al. also reported a high percentage of LRSA in Rajasthan (20.3\%) [40]. On the other context, the current finding is higher than the global rates reported in the LEADER or ZAAPS studies [41, 42]. This could be due to the availability of linezolid in the Egyptian market, its use as an empiric treatment in our locality and absence of guidelines that control its use. One of the main reasons of antibiotic resistance is the rebellious nature of biofilms produced by these pathogens. In this study, 85/116 (73\%) of isolates were identified as biofilm producers, that is compatible with other studies investigated biofilm production by $S$. aureus isolated from wound samples [43,
44]. Our study focused on the development of promising alternative agents for treatment of these serious infections such as $\mathrm{ZnO}-\mathrm{NPs}$. Interestingly, $\mathrm{ZnO}$-NPs were identified by several reports as non-toxic to human cells [45]. $\mathrm{ZnO}$-NPs should penetrate into bacterial cells to express the antibacterial activity [46]. Therefore, the broth dilution assay can be considered as accurate and confirmative method for identification of antibacterial activity of $\mathrm{ZnO}$ NPs [47]. By using the broth dilution method, our study showed that, MICs of $\mathrm{ZnO}-\mathrm{NPs}$ among S. aureus isolates were ranging from 128 to $2048 \mu \mathrm{g} / \mathrm{ml}$. Other studies have also reported that bactericidal effect of $\mathrm{ZnO}-\mathrm{NPs}$ is concentration-dependent [48-50]. By use of sub MICs of $\mathrm{ZnO}-\mathrm{NPs}(68-1000 \mu \mathrm{g} / \mathrm{ml})$, the biofilm formation among the study isolates was decreased up to $76.47 \%(65 / 85)$. This was comparatively higher than that used by Jesline et al. who detected $(100 / 200 / 500 \mu \mathrm{g} / \mathrm{ml})$ concentrations were able to inhibit bacterial growth and biofilm formation of all S. aureus isolates [51] and lower than that used by Jasim et al. who observed that, the highest rate of biofilm inhibition among VRSA was $73.95 \pm 2.17 \%$ at $10.00 \mu \mathrm{g} / \mathrm{ml}$ of $\mathrm{ZnO}$-NPs [52]. Similar results were reported by Mahamuni et al., who reported $67.3 \%$ biofilm inhibition [53] and Abd El-Hamid who reported a percentage of $(99.73 \%)$ of biofilm inhibition among S. aureus isolates [54]. With the use of sub MICs of ZnO-NPs on $S$. aureus isolates, resistance to oxacillin (MRSA) decreased from 81.90 to $13.30 \%$, VRSA decreased from 33.60 to $0 \%$ and, LRSA decreased from 29.30 to $0 \%$. Using $Z$ test, the decrease in MRSA, VRSA and LRSA was statistically significant as $\mathrm{Z}$ score were $11.10,6.85$ and 6.47 respectively (all these values are significant). These findings agree with Ghazi and Alsammak, who observed that the efficacy of vancomycin was improved in combination with $\mathrm{ZnO}$ nanoparticles (MICs of vancomycin decreased from $(2500-5000 \mu \mathrm{g} / \mathrm{mL})$ to $(39-78.13 \mu \mathrm{g} / \mathrm{mL})$ when mixed with $\mathrm{ZnO} 20 \mathrm{~nm}$. [55]. Also Namasivayam et al. and Thati et al. reported that nanoparticles showed enhanced activity with several antibiotics against all the tested $S$. aureus $[56,57]$. Several previous studies investigated the prevalence of mec $A$, van $A$ and $c f r$ genes among $S$. aureus isolates $[34,58,59]$. However, information about the expression levels of these genes is very little. Therefore, the current study assessed the expression levels of these genes by investigating RNA of S. aureus isolates before and after application of $\mathrm{ZnO}$-NPs by quantitative rt-PCR. Mec A gene was expressed in 100\% of oxacillin resistant isolates and van $A$ gene was expressed in $(22 / 39 ; 50 \%)$ of the VRSA isolates. $C f r$ gene expression was detected in (29/34; 85.30\%) of LRSA isolates, this high rate could be explained by horizontal spread of $c f r$ gene among different species [60]. Cfr-mediated resistance was also identified in $100 \%$ of LRSA isolates in previous studies [12]. 


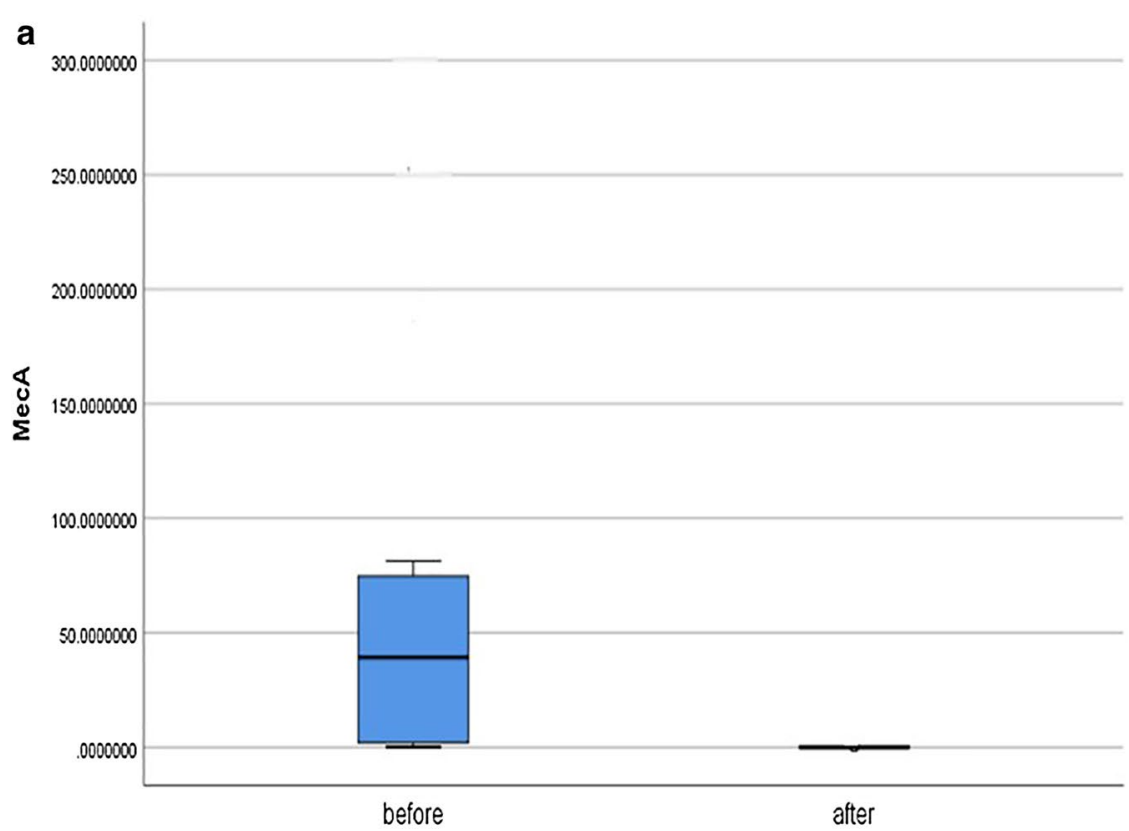

b

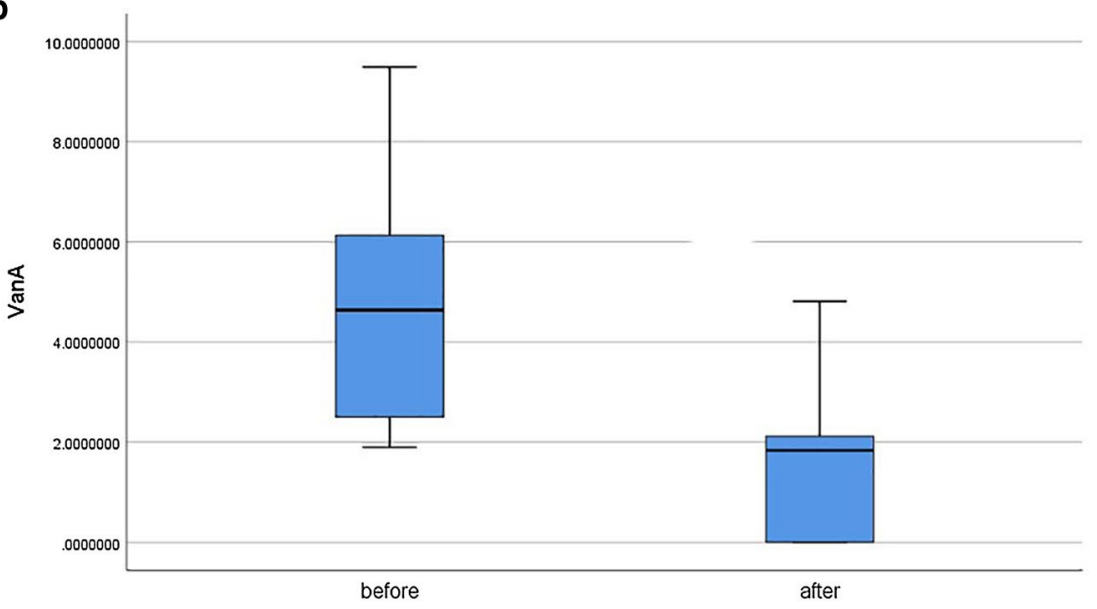

C

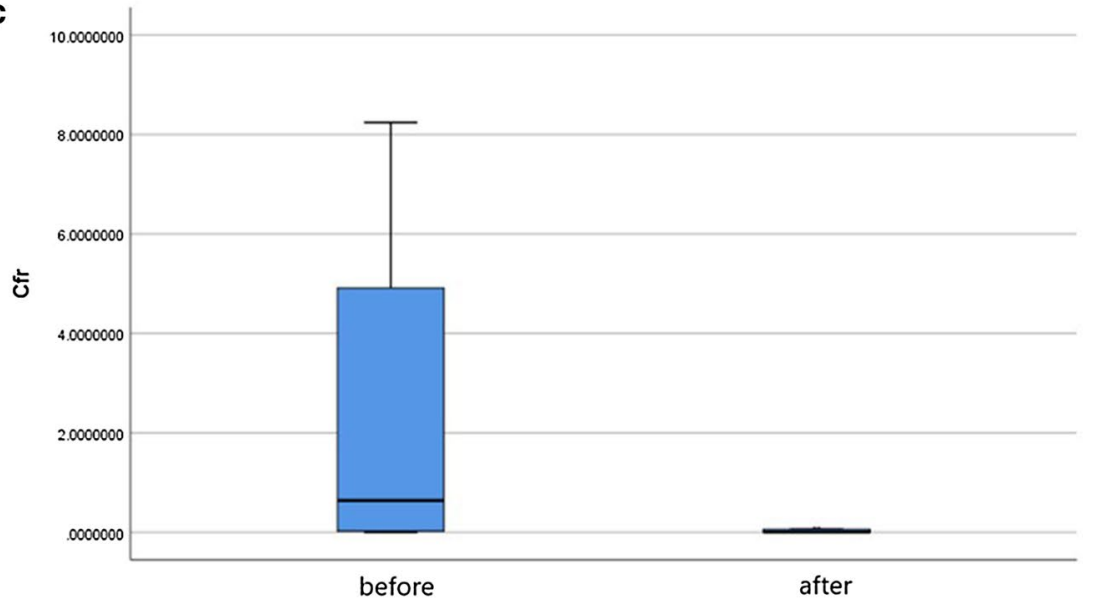

Fig. 5 a Expression of MecA gene before and after ZnO-NPs application, P-value =0.005. $\mathbf{b}$ Expression of vanA gene before and after ZnO-NPs application, $\mathrm{P}$-value $=0.001$. $\mathbf{c}$ Expression of $\mathrm{cfr}$ gene before and after ZnO-NPs application, $\mathrm{P}$-value $=0.002$ 
Table 3 ROC curve analysis

\begin{tabular}{llllll}
\hline Gene & $\begin{array}{l}\text { Area } \\
\text { under the } \\
\text { curve }\end{array}$ & $\begin{array}{l}\text { 95\% } \\
\text { confidence } \\
\text { interval }\end{array}$ & P value & $\begin{array}{l}\text { Sensitivity } \\
\text { (\%) }\end{array}$ & $\begin{array}{l}\text { Specificity } \\
\text { (\%) }\end{array}$ \\
\hline fnbA & 0.83 & $0.65-1.00$ & 0.01 & 71.70 & 85.00 \\
ica A & 0.79 & $0.62-0.95$ & 0.01 & 66.70 & 83.00 \\
icaD & 0.84 & $0.73-0.95$ & 0.01 & 66.00 & 83.30 \\
mec A & 0.93 & $0.85-1.00$ & 0.01 & 88.00 & 97.00 \\
VanA & 0.893 & $0.758-1$ & 0.002 & 76 & 92 \\
Cfr & 0.859 & $0.721-0.997$ & 0.001 & 62 & 87 \\
\hline
\end{tabular}

The expression levels of mec $A$, van $A$ and $c f r$ genes after treating the isolates with sub-MIC of $\mathrm{ZnO}$-NPs were significantly reduced with $\mathrm{p}$ values; $0.005,0.002$ and 0.001 respectively. Also Kadiyala et al. who examined the effect of $\mathrm{ZnO}-\mathrm{NP}$ on different genes of S. aureus by microarray reported that 375 were significantly down-regulated after application of $\mathrm{ZnO}-\mathrm{NP}$ [61]. To best of our knowledge, the current study is the first incidence of investigating the effect of $\mathrm{ZnO}$-NPs on levels of gene expression in S. aureus isolates in Egypt and Middle East. The current study has also investigated the expression levels of biofilm encoding genes before and after application of $\mathrm{ZnO}-$ NPs. The expression of fnb $A$, ica $A$, ica $B$ and ica $D$ genes were investigated; the most frequently expressed genes were ica $A$ and $f n b A$ (expressed in $100 \%$ of isolates), followed by ica $D$ gene which has expressed in $82.6 \%$ of isolates. However, ica $B$ gene has not expressed in the study isolates. The expression of fnb $A, i c a A$ and ica $D$ genes after treating of isolates with sub MIC of ZnO-NPs were significantly reduced and $\mathrm{p}$ values were $0.008,0.005$ and 0.005 respectively. That agrees with Abd El-Hamid et al. who demonstrated that the transcriptional levels of icaA was remarkably decreased with mean values of fold changes up to 0.15 , and Shakerimoghaddam et al., who reported significant reductions 10.2-fold decrease in the gene expression of icaA gene expression among $S$. aureus isolates after application of sub MIC ZnO-NPs [45, 63]. However, Gheidar et al. reported that the expression of $i c a A$ and icaD genes in the presence of $\mathrm{ZnO}$-NPs were not significantly reduced compared to the control samples. But, exposure to nanoparticles reduced the expression of $f n b A$ and $f n b B$ genes from 0.46 to 0.06 [62].

\section{Conclusion}

In this study, promising activities of $\mathrm{ZnO}-\mathrm{NPs}$ as an antibacterial agent against MRSA, VRSA and LRSA as well as anti-biofilm activity were reported. The study demonstrated that the $\mathrm{ZnO}$-NPs are able to reduce the expression levels of the ica $A$, ica $D$ and fnb $A$ genes (the main genes associated with biofilm formation in $S$. aureus) and also reduce the expression levels of the mec $A$, van $A$ and $c f r$ genes (the main genes associated with resistance to methicillin, vancomycin and linezolid in $S$. aureus). Finally, we recommend the use of $\mathrm{ZnO}-\mathrm{NPs}$ for resistant infections. However, further researches must be done to evaluate the safety of $\mathrm{ZnO}$-NPs use in vitro and in vivo.

\begin{abstract}
Abbreviations
LRSA: Linezolid resistant S. aureus; MIC: Minimum inhibitory concentration; MRSA: Methicillin resistant S. aureus; ROC curve: Receiver operating characteristic curve; rt-PCR: Reverse transcriptase-polymerase chain reaction; RQ: Relative quantity; VISA: Vancomycin intermediate S. aureus; VRSA: Vancomycin resistant S. aureus; ZnO-NPs: Zinc oxide nanoparticles.
\end{abstract}

\section{Supplementary Information}

The online version contains supplementary material available at https://doi. org/10.1186/s12941-021-00459-2.

Additional file 1: Table S1. Mean relative quantity (RQ) of gene expression before and after application of ZnO NPs.

Acknowledgements

We thank the health care workers in Minia University hospital for their cooperation

\section{Authors' contributions}

Concept and design of study: RMMK, SHZ and WMA. Experiments: AIZ, WMA, $\mathrm{SHZ}$ and RMMK. The manuscript was drafted by RMMK, AIZ, WMA and SHZ and revised by all authors. All authors read and approved the final manuscript.

Funding

None.

Availability of data and materials

All data generated or analyzed during this study are included in this article and Additional file 1.

\section{Declarations}

\section{Ethics approval and consent to participate}

This study was carried following the guidelines of the declaration of Helsinki and approved by the Medical Ethics Committee of Faculty of medicine, Minia University, Egypt. Informed consent was obtained from each participant.

Consent for publication

Not applicable.

Competing interests

The authors declare that they have no competing interests.

Received: 10 March 2021 Accepted: 12 August 2021

Published online: 21 August 2021

References

1. Chambers HF, Deleo FR. Waves of resistance: Staphylococcus aureus in the antibiotic era. Nat Rev Microbiol. 2009;7(9):629-41.

2. Taylor TA, Unakal CG. Staphylococcus aureus. In: StatPearls. Treasure Island (FL): StatPearls Publishing. 2020.

3. Kim C, Milheirico C, Gardete S, Holmes MA, Holden MT, de Lencastre H, et al. Properties of a novel PBP2A protein homolog from Staphylococcus 
aureus strain LGA251 and its contribution to the beta-lactam-resistant phenotype. J Biol Chem. 2012;287(44):36854-63.

4. Cong Y, Yang S, Rao X. Vancomycin resistant Staphylococcus aureus infections: a review of case updating and clinical features. J Adv Res. 2019;21:169-76. https://doi.org/10.1016/j.jare.2019.10.005.

5. Chang S, Sievert DM, Hageman JC, Boulton ML, Tenover FC, Downes FP, et al. Infection with vancomycin-resistant Staphylococcus aureus containing the vanA resistance gene. N Engl J Med. 2003;348(14):1342-7.

6. Patel R, Piper K, Cockerill FR 3rd, Steckelberg JM, Yousten AA. The biopesticide Paenibacillus popilliae has a vancomycin resistance gene cluster homologous to the enterococcal VanA vancomycin resistance gene cluster. Antimicrob Agents Chemother. 2000;44(3):705-9.

7. Swaney SM, Aoki H, Ganoza MC, Shinabarger DL. The oxazolidinone linezolid inhibits initiation of protein synthesis in bacteria. Antimicrob Agents Chemother. 1998;42:3251-5.

8. Tsiodras S, Gold HS, Sakoulas G, et al. Linezolid resistance in a clinical isolate of Staphylococcus aureus. Lancet. 2001;358:207-8.

9. Wilson P, Andrews JA, Charlesworth R, Walesby R, Singer M. Linezolid resistance in clinical isolates of Staphylococcus aureus. J Antimicrob Chemother. 2003:51:186-8.

10. Meka VG, Pillai SK, Sakoulas G, Wennersten C, Venkataraman L. Linezolid resistance in sequential Staphylococcus aureus isolates associated with a T2500A mutation in the 23SrRNA gene and loss of a single copy of rRNA. J Infect Dis. 2004;190:311-7.

11. Mendes RE, Deshpande LM, Castanheira M, DiPersio J, Saubolle MA, Jones RN. First report of cfr-mediated resistance to linezolid in human staphylococcal clinical isolates recovered in the United States. Antimicrob Agents Chemother. 2008;52(6):2244-6.

12. Morales G, Picazo JJ, Baos E, Candel FJ, Arribi A, Peláez B, Andrade R, de la Torre MA, Fereres J, Sánchez-García M. Resistance to linezolid is mediated by the cfr gene in the first report of an outbreak of linezolid-resistant Staphylococcus aureus. Clin Infect Dis. 2010;50(6):821-5.

13. Lister JL, Horswill AR. Staphylococcus aureus biofilms: recent developments in biofilm dispersal. Front Cell Infect Microbiol. 2014;4:178. https:// doi.org/10.3389/fcimb.2014.00178.

14. Fitzpatrick F, Humphreys $\mathrm{H}$, O'Gara JP. Evidence for icaADBC-independent biofilm development mechanism in methicillin-resistant Staphylococcus aureus clinical isolates. J Clin Microbiol. 2005;43(4):1973-6.

15. O'Neill E, Pozzi C, Houston P, Smyth D, Humphreys H, Robinson DA, et al. Association between methicillin susceptibility and biofilm regulation in Staphylococcus aureus isolates from device-related infections. J Clin Microbiol. 2007:45:1379-88.

16. Raghunath A, Perumal E. Metal oxide nanoparticles as antimicrobial agents: a promise for the future. Int J Antimicrob Agents. 2017:49:137-52.

17. Tayel AA, El-Tras WF, Moussa S, El-Baz AF, Mahrous H, Salem MF, Brimer L. Antibacterial action of zinc oxide nanoparticles against foodborne pathogens. J Food Saf. 2011;31:211-8.

18. Król A, Pomastowski P, Rafińska K, Railean-Plugaru V, Buszewski B. Zinc oxide nanoparticles: synthesis, antiseptic activity and toxicity mechanism. Adv Colloid Interface Sci. 2017;249:37-52.

19. Andrews JM. Determination of minimum inhibitory concentrations. J Antimicrob Chemother. 2001;48:5-16.

20. CLSI. Performance standards for antimicrobial susceptibility testing. 29th ed. Wayne, PA, USA: CLSI supplement M100; clinical and laboratory standards institute; 2019.

21. Stepanović S, Vuković D, Hola V, et al. Quantification of biofilm in microtiter plates: overview of testing conditions and practical recommendations for assessment of biofilm production by staphylococci. APMIS. 2007;115(8):891-9.

22. Rohde H, Knobloch JK, Horstkotte MA, Mack D. Correlation of Staphylococcus aureus icaADBC genotype and biofilm expression phenotype. J Clin Microbiol. 2001;39(12):4595-6.

23. Kiem S, Oh WS, Peck KR, Lee NY, Lee JY, Song JH, Choe KW. Phase variation of biofilm formation in Staphylococcus aureus by IS 256 insertion and its impact on the capacity adhering to polyurethane surface. J Korean Med Sci. 2004;19:779-82.

24. Vancraeynest D, Hermans K, Haesebrouck F. Genotypic and phenotypic screening of high and low virulence Staphylococcus aureus isolates from rabbits for biofilm formation and MSCRAMMs. Vet Microbiol. 2004;103(3-4):241-7.
25. Jonas D, Speck M, Daschner FD, Grundmann H. Rapid PCR-based identification of methicillin-resistant Staphylococcus aureus from screening swabs. J Clin Microbiol. 2002;40(5):1821-3.

26. Clark NC, Cooksey RC, Hill BC, Swenson JM, Tenover FC. Characterization of glycopeptide-resistant enterococci from U.S. hospitals. Antimicrob Agents Chemother. 1993;37(11):2311-7.

27. Higuera-Llantén S, Vásquez-Ponce F, Barrientos-Espinoza B, Mardones FO, Marshall SH, Olivares-Pacheco J. Extended antibiotic treatment in salmon farms select multiresistant gut bacteria with a high prevalence of antibiotic resistance genes. PLoS ONE. 2018;13(9): e0203641.

28. Livak KJ, Schmittgen TD. Analysis of relative gene expression data using real-time quantitative PCR and the 2(-Delta Delta C (T)) method. Methods. 2001;25(4):402-8.

29. Monday SR, Bohach GA. Use of multiplex PCR to detect classical and newly described pyrogenic toxin genes in staphylococcal isolates. J Clin Microbiol. 1999:37(10):3411-4.

30. Falagas ME, Karageorgopoulos DE, Leptidis J, Korbila IP. MRSA in Africa: filling the global map of antimicrobial resistance. PLoS ONE. 2013;8(7): e68024.

31. Abouelfetouh A. The status of methicillin resistance among Egyptian Staphylococcus aureus isolates: an overview. Infect Disord Drug Targets. 2017;17(1):67-9.

32. Gitau W, Masika M, Musyoki M, Museve B, Mutwiri T. Antimicrobial susceptibility pattern of Staphylococcus aureus isolates from clinical specimens at Kenyatta National Hospital. BMC Res Notes. 2018;11(1):226.

33. Ghoniem EM, El Hendawy GR, Abdel Moteleb TM, Hassan HA, El Refai Khalil HA. Characterization of vancomycin-resistant Staphylococcus aureus in the National Liver Institute. Menoufia Med J. 2014;27:825-32.

34. Saeed A, Ahsan F, Nawaz M, labal K, Rehman KU, IjazT. Incidence of vancomycin resistant phenotype of the methicillin resistant Staphylococcus aureus isolated from a tertiary care hospital in Lahore. Antibiotics. 2019;9(1):3. https://doi.org/10.3390/antibiotics9010003.

35. Antonanzas F, Lozano C, Torres C. Economic features of antibiotic resistance: the case of methicillin-resistant Staphylococcus aureus. Pharmacoeconomics. 2015;33(4):285-325. https://doi.org/10.1007/ s40273-014-0242-y.

36. Gardete S, Tomasz A. Mechanisms of vancomycin resistance in Staphylococcus aureus. J Clin Investig. 2014;124:2836-40.

37. Shariati A, Dadashi M, Moghadam MT, van Belkum A, Yaslianifard S, Darban-Sarokhalil D. Global prevalence and distribution of vancomycin resistant, vancomycin intermediate and heterogeneously vancomycin intermediate Staphylococcus aureus clinical isolates: a systematic review and meta-analysis. Sci Rep. 2020;10(1):12689.

38. Ashour HM, el-Sharif A. Microbial spectrum and antibiotic susceptibility profile of gram-positive aerobic bacteria isolated from cancer patients. J Clin Oncol. 2007;25(36):5763-9.

39. ElSayed N, Ashour M, Amine AEK. Vancomycin resistance among Staphylococcus aureus isolates in a rural setting, Egypt. Germs. 2018;8(3):134-9.

40. Singh $H$, Atray M, Modi PK. Antibiotic susceptibility pattern of methicillin resistant Staphylococcus aureus in tertiary care center at southern Rajasthan. IJPSR. 2014;5(2):607-11.

41. Flamm RK, Mendes RE, Hogan PA, Streit JM, Ross JE, Jones RN. Linezolid surveillance results for the United States (LEADER Surveillance Program 2014). Antimicrob Agents Chemother. 2016;60(4):2273-80.

42. Mendes RE, Deshpande L, Streit JM, Sader HS, Castanheira M, Hogan PA, Flamm RK. ZAAPS programme results for 2016: an activity and spectrum analysis of linezolid using clinical isolates from medical centres in 42 countries. J Antimicrob Chemother. 2018;73(7):1880-7.

43. Kaur DC, Wankhede S. Biofilm formation and antimicrobial susceptibility pattern of methicillin resistant Staphylococcus Aureus from wound infection. APJHS. 2014;1:322-8.

44. Neopane P, Nepal HP, Shrestha R, Uehara O, Abiko Y. In vitro biofilm formation by Staphylococcus aureus isolated from wounds of hospitaladmitted patients and their association with antimicrobial resistance. Int J Gen Med. 2018;11:25-32.

45. Colon G, Ward BC, Webster TJ. Increased osteoblast and decreased Staphylococcus epidermidis functions on nanophase $\mathrm{ZnO}$ and $\mathrm{TiO}_{2} . J$ Biomed Mater Res. 2006;78(3):595-604.

46. Mirhosseini M, Firouzabadi FB. Antibacterial activity of zinc oxide nanoparticle suspensions on food-borne pathogens. Int J Dairy Technol. 2013;66:291-5. 
47. Negi H, Agarwal T, Zaidi MGH, Goel R. Comparative antibacterial efficacy of metal oxide nanoparticles against Gram negative bacteria. Ann Microbiol. 2012;62:765-72.

48. Reddy KM, Feris K, Bell J, Wingett DG, Hanley C, Punnoose A. Selective toxicity of zinc oxide nanoparticles to prokaryotic and eukaryotic systems. Appl Phys Lett. 2007;90(213902):2139021-3.

49. Sirelkhatim A, Mahmud S, Seeni A, Kaus NHM, Ann LC, Bakhori SKM, Hasan H, Mohamad D. Review on zinc oxide nanoparticles: antibacterial activity and toxicity mechanism. Nanomicro Lett. 2015;7(3):219-42.

50. Souza RCD, Haberbeck LU, Riella HG, Ribeiro DH, Carciofi BA. Antibacterial activity of zinc oxide nanoparticles synthesized by solochemical process. Braz J Chem Eng. 2019;36:885-93.

51. Jesline A, John NP, Narayanan PM, et al. Antimicrobial activity of zinc and titanium dioxide nanoparticles against biofilm-producing methicillinresistant Staphylococcus aureus. Appl Nanosci. 2015;5:157-62.

52. Jasim NA, Al-Gashaa FA, Al-Marjani MF, Al-Rahal AH, Abid HA, Al-Kadhmi NA, Jakaria M, Rheima AM. ZnO nanoparticles inhibit growth and biofilm formation of vancomycin-resistant $\mathrm{S}$ aureus (VRSA). Biocatal Agric Biotechnol. 2020;29: 101745.

53. Mahamuni PP, Patil PM, Dhanavade MJ, Badiger MV, Shadija PG, Lokhande AC, Bohara RA. Synthesis and characterization of zinc oxide nanoparticles by using polyol chemistry for their antimicrobial and antibiofilm activity. Biochem Biophys Rep. 2019;17:71-80.

54. El-Hamid MIA, El-Naenaeey ESY, Kandeel TM, et al. Promising antibiofilm agents: recent breakthrough against biofilm producing methicillin-resistant Staphylococcus aureus. Antibiotics. 2020;9(10):667.

55. Thamer R, Alsammak EG. Synergistic effect of zinc oxide nanoparticles and vancomycin on methicillin resistant Staphylococcus aureus. J Life Bio Sci Res. 2020. https://doi.org/10.38094/jlbsr1332.

56. Venubabu Thati A, Roy S, Prasad MA, Shivannavar CT, Gaddad SM. Nanostructured zinc oxide enhances the activity of antibiotics against Staphylococcus aureus. Biosci Technol J. 2010;1(2):64-9.
57. Namasivayam S, Prasanna M, Subathra S. Synergistic antibacterial activity of zinc oxide nanoparticles with antibiotics against human pathogenic bacteria. J Chem Pharm Res. 2015;7:133-8.

58. Mashaly M, El-Mashad N, El-deeb H. Detection of VanA type vancomycin resistance among MRSA isolates from an emergency hospital in Egypt. Comp Clin Pathol J. 2019;28(4):971-6.

59. Al-Bdery ASJ, Mohammad GJ, Hussen B. Vancomycin and linezolid resistance among multidrug-resistant Staphylococcus aureus clinical isolates and interaction with neutrophils. Gene Rep J. 2020;21(2):10074-88.

60. Diaz L, Kiratisin P, Mendes RE, Panesso D, Singh KV, Arias CA. Transferable plasmid-mediated resistance to linezolid due to cfr in a human clinical isolate of Enterococcus faecalis. Antimicrob Agents Chemother. 2012;56(7):3917-22

61. Kadiyala U, Turali-Emre ES, Bahng JH, Kotov NA, VanEpps JS. Unexpected insights into antibacterial activity of zinc oxide nanoparticles against methicillin resistant Staphylococcus aureus (MRSA). Nanoscale. 2018;10(10):4927-39. https://doi.org/10.1039/c7nr08499d.

62. Shakerimoghaddam A, Razavi D, Rahvar F, Khurshid M, Ostadkelayeh SM, Esmaeili SA, Khaledi A, Eshraghi M. Evaluate the effect of zinc oxide and silver nanoparticles on Biofilm and icaA gene expression in methicillinresistant Staphylococcus aureus isolated from burn wound infection. J Burn Care Res. 2020:41(6):1253-9.

63. Gheidar H, Haddadi A, Kalani BS, Amirmozafari N. Nanoparticles impact the expression of the genes involved in biofilm formation in S. aureus, a model antimicrobial-resistant species. J Med Bacteriol. 2018;7(3-4):30-41.

\section{Publisher's Note}

Springer Nature remains neutral with regard to jurisdictional claims in published maps and institutional affiliations.
Ready to submit your research? Choose BMC and benefit from:

- fast, convenient online submission

- thorough peer review by experienced researchers in your field

- rapid publication on acceptance

- support for research data, including large and complex data types

- gold Open Access which fosters wider collaboration and increased citations

- maximum visibility for your research: over $100 \mathrm{M}$ website views per year

At BMC, research is always in progress.

Learn more biomedcentral.com/submissions 